\title{
Research on Cultivation Mode of Applied Talents Majoring in Computer of New Local Undergraduate Universities
}

\author{
Dan Su \\ Heihe University, Heihe, Heilongjiang, 164300
}

Keywords: employment orientation; new local undergraduate colleges and universities; computer major; talents cultivation mode

\begin{abstract}
In terms of the problems in the process of cultivating talents majoring in computer and characteristics of new local undergraduate colleges and universities, concrete measures have been discussed on employment-oriented talents who major in computer of colleges and universities in accordance with course design of computer science and technology, teaching method reform and teachers construction.
\end{abstract}

\section{Introduction}

With the development of our society and economy, there is a high demand for collage graduates major in computer in society. For graduates, they have diverse employment choices. In recent years, college graduates major in computer have been influenced by the expanding education size of computer science. Meanwhile, the employment rate and quality have also dropped and it is hard for graduates who specialize in computer to take up an occupation.

The status of employment not only evaluates the teaching standards and quality and affects the sustainable development of the universities directly, but also has effects on the stability of our society. There is an indisputable fact that it is difficult for graduates who specialize in computer to obtain a job. Therefore, according to the status of local places, the universities must modify cultivation scheme of professional talents, establish the propose positioning of talents cultivation and create new teaching plans, course systems and teaching methods, as well as teach students in accordance of their aptitude on the grounds of the situation and social demands.

\section{The Current Situation of Cultivating Talents Majoring in Computer of New Local Undergraduate Colleges and Universities}

\subsection{Undefined educational goals}

There is no comparison between students in newly-found local undergraduate universities and those in nationally ranked universities for student pools and teaching conditions. However, newlyfound local universities have studied and adopted target positioning of talents cultivation, professional cultivation schemes and teaching plan that are similar to the key colleges. For this, professional positioning of computer in newly-found local universities has been disconnected with social demands. Neither scientific advantages nor technical advantages can be owned by graduates. There is a structural contradiction between professional cultivation and social need. Expectation for talents major in computer from society presents the demand of diversity. Due to the distinct deviation in talents cultivation positioning of computer in newly-found local undergraduate universities, there is a shortage of reasonable classification and the targets of meeting social requirements is undefined, which lead the structure gets unreasonable. Blindness can be found in the design of teaching content and professional knowledge structure of students becomes unreasonable, which make them fail to satisfy the employment demand.

\subsection{Relatively lagging course system and unreasonable curriculum}

The course system is relatively lagging, the teaching methods and content are out of date, and it 
is badly disconnected with the current development of computer technology and cannot meet the needs of the market. There are many theoretical knowledge, namely, many theories, less practice, more foundations, less reviews, more talks, less activities, resulting in fewer courses for students to practice their innovative ability, less time for students to develop and create. There is a lack of practice. Most colleges use curriculum design and graduation design as the link of internship practice. The practice sessions feature one-sided discipline, decoupling from enterprise application, lack of systematic, comprehensive and sufficient practical links, often resulting in students with poor practical ability, so it is difficult to meet the needs of employers.

The front-line teachers are loaded with teaching tasks and have no time to work on developing and researching applied projects. They teach only for teaching. Because of lacking practice and application experiences, more better guidance advices can not be offered to students in computer application. Teachers fail to give play to their professional skills due to the lack of employment mechanisms and incomplete stimulating mechanisms, which lead the teachers to be thwarted in positivity, initiative and creativity. It is hard to keep pace with high-quality teachers and equipment and ensure teaching quality.

\section{Employment Influence on Talents Majoring in Computer of New Local Undergraduate Colleges and Universities}

The reason why graduates major in computer are homogeneous and indistinctive and live apart from market is that there are no clear educational goals of computer in newly-found local undergraduate universities, as well as the relatively lagging course system, unreasonable curriculum and lagging construction of teaching staff. Along with a great number of students who specialize in computer and software engineering, employment has been directly impacted for graduates of newly-found local undergraduate universities.

Effective connection has not been established between talent market and college education, so the updating speed of professional knowledge cannot be followed. Platforms, tools and professional techniques being used by employers are not mentioned in the class. Coupled with project experiences in scanty, no practice and job experiences and weak manipulative ability, students fail to answer questions on professional knowledge, application technology and the process and details of research and development when participating in interview.

Employment guidance center have been established by newly-found local undergraduate universities, but employment guidance and service work are still on the surface because of lacking experiences and systematization. Firstly, the employment guidance work team lacks professionalism. At present, the personnel engaged in employment guidance work are basically served by the relevant leaders and staff members who are engaged in student management work and the counselors of the graduating class. There is no systematic learning and specialized training, and little is known about the real needs of society, industry and business. Secondly, the employment guidance work only focuses on the form. For example, when we are close to employment every year, we only hold a mobilization meeting for graduate employment, roughly explain employment policies and analyze the employment situation, upload career selection skills in theory, provide some employment information, etc., and ignore planning colleges' career and guiding the future, especially in training and guiding employment concept and quality for students in the long term and lacks professional and personalized services for them.

\section{Individual Factor}

For newly-found local undergraduate universities, enrollment in computer is out of expectation. Some problems can be found in quality of student resource. Some students dislike the majors they choose. The other is less initiative to study and have no interest in learning, and they have no solid foundation of professional knowledge and basic techniques, with no skills mastered when graduating.

To sum up, the reason why low employment rate of students major in computer is mainly that 
they lack basic literacy and profession quality that they should have. Other factors such as infirm foundation, inferior academy, weak manipulative ability and nothing special also affect the employment rate.

How to formulate reasonable cultivation mode suitable for talents major in computer, adjust professional positioning and train high-quality personnels who can meet social requirements on the basis of conditions and features and how to make countermeasures in line with changeable employment situation increase employment rate of talents major in computer of newly-found local undergraduate universities are key problems for enhancing the employment rate and also for the sound and sustainable development for the major.

\section{Adjust Curriculum and Create Reasonable Course System}

Setting clear training targets and establishing training scheme. For new local undergraduate universities, their goal is to cultivate the students who are popularized by society to hunt for a suitable job. Therefore, curriculums should be in line with teaching and the fact of management and meet the demands from society to improve employment adaptation of students. According to the training targets, course structure can be designed, teaching outlines have been prepared and teaching materials also can be collected.

Course system is made on the basis of dynamic and developed principles. As technologies of computer have developed rapidly, professional course design (compulsory courses, optional courses and practical courses) is supposed to keep pace with the development of new technology and constantly amend training schemes and contents. For example, small direction can be set in optional courses to keep in step with the trend of profession development and actual requirements in society.

Course system can be designed to improve application ability. Newly-found local undergraduate universities need to strive for more money to improve teaching facilities and experimental conditions in the school; strengthen cooperation with relevant enterprises in the region, and actively build an off-campus practice base. It is necessary to pay attention to the teaching and content arrangement of the experimental class and incorporate the extracurricular practice activities into the overall training program to improve the students' enthusiasm for participating in the practical class, in order to cultivate students' innovative consciousness and practical ability.

The tutorial system has been adopted to improve the talent training program. In view of the shortage of tutors in newly-built local undergraduate colleges, students in freshmen and sophomores can manage their classes, and the courses are designed as a class system. However, appropriate offcampus internships should be arranged to enable students to discover their professional interests and develop their internships. On their own professional direction, students can choose their own instructor according to their own professional direction (the supervisor is mainly responsible for the student's learning, and the tutor is responsible for the daily management of the student), rather than selecting the thesis supervisor when writing the graduation thesis. The tutorial system enables students to build a learning team according to their own interests so as to improve their self-study ability; they can teach students in accordance of their aptitude with majors, small directions and modularity on the basis of students' hobbies. Students can prepare for graduation thesis in advance. They should have a good experiment and practice class with purpose and cultivate your own skills and innovation ability.

\section{Improve Teaching Method and Strengthen the Teaching Staff Construction}

The industry-university-research cooperation should be sought actively. Newly-found universities have no experiences, with weak teachers' research strength and low social recognition. Under the circumstance, for one thing, we must strengthen our own construction, improve the construction of laboratory and training bases, and encourage teachers to actively participate in the project or the project declaration via the project teaching in order to accumulate experiences for the development of industry-university-research cooperation; for the other thing, it must seize the opportunity to strengthen cooperation with relevant enterprises in the region, actively participate in 
the technological innovation of regional enterprises so as to obtain the practice outside the school directly. To a certain degree, the shortage of school funds as well as the backwardness and inadequacy of teaching and research equipment can be solved to enhance the school's ability to cultivate innovation and expand the actual training conditions.

Industry-university-research cooperation leads the teachers have access to the deep understanding for enterprises production with organic bond of theories and practices. It also can transform teachers from teaching to researching and develop a team with dual-qualification teachers. This is conducive to the current situation where students present poor work ability and the theory has divorced from practice.

The training of teaching staff should be paid attention to. Teacher construction mechanism should be improved to give play to the enthusiasm, initiative, and creativity of teachers, and give play to the skills of them. On the one hand, in order to train "dual-qualification" teachers, it is necessary to send professional teachers to relevant enterprises or schools for further study in stages and in batches to understand the cutting-edge technology and development trends of computers and to improve their practical ability and research and development capabilities. On the other hand, computer technicians in enterprises can be hired as training teachers.

By organizing Computer Science and Technology Association in the form of colleges' communities, a bond that can organize students to join in extra-curricular activities related to science and technology and culture such as Academic Science and Technology Forum, Academic Paper Competition of Computer, Computer Software Design Competition, Linux Competition, Case Making and Project Development is built. Students should be encouraged to participate in start-up activities to enhance their practice and train their manipulative ability and innovation consciousness.

The tutorial system has been implemented and it means that teachers should completely take care of students' thought, help them on study, life and work and guide them how to seek for a job. Employment theory guidance runs through the entire process of study and students are made to formulate plan for life and dream. Teachers should change students' employment idea and ensure lofty job-seeking moral and occupational moral and establish correct growth outlook and employment outlook. Meanwhile, teachers should have students cope with different relations between social need and personal achievement, career and life as well as individual and collectivity.

Employment guidance is not just a meeting that mobilizes graduates to seek for a job, generally explains employment policies and analyzes the situation, shares some skills on how to choose a job in theory or provides some employment information. It also offers professional and personalized service in line with the students' ambition, as well as guides them to make occupational plan and further plan well.

\section{Conclusion}

Many disadvantages are found in talents cultivation mode of computer in newly-found local undergraduate universities. Only if the colleges focus on reform and innovation, constantly learn advanced teaching experiences and successful talents cultivation mode and be based on their characteristics, a cultivation mode of talents major in computer which is suitable for regional economic development and meets the need of social development can be explored and plenty of talents pool can be also provided for regional development and information industry.

\section{Acknowledgment}

Foundation: Higher Education Reform Project in Heilongjiang Province, SJGY0207

\section{References}

[1] Li Guo. The Significance of Industry-University-Research Cooperation in Advanced Colleges [J]. Journal of China West Normal University, 2006, (2).

[2] Zhang Deying. Discussion on the Ways of Establishing the Science and Technology Innovation 
System of Industry-University-Research Cooperation in Local Universities [J]. Journal of Sichuan University of Science and Technology (Social Science Edition), 2007, (2).

[3] Pan Wei. Preliminary Study on the Training Mode of Applied Talents Major in Computer in Colleges [J]. Consumer Guide, 2010, (1).

[4] Xu Hong. How to implement the "employment-oriented” Talent Cultivation Mode in Higher Vocational Computer Science [J]. Journal of Shandong Institute of Commerce and Technology, 2006, (6). 